\title{
Carbonyl sulfide and dimethyl sulfide exchange between trees and the atmosphere
}

\author{
Chunmei Geng, Yujing Mu* \\ State Key Laboratory of Environmental Chemistry and Ecotoxicology, Research Center for Eco-Environmental Sciences, \\ Chinese Academy of Sciences, Beijing 100085, China
}

Received 25 February 2005; received in revised form 4 October 2005; accepted 4 October 2005

\begin{abstract}
The exchange rates of carbonyl sulfide (COS) and dimethyl sulfide (DMS) between 19 tree species and the atmosphere were investigated under natural field conditions using a static enclosure. Most of the investigated trees acted as sinks for atmospheric COS and a few trees, such as Salix matsudana Koidz. and Ulmus pumila L. could emit COS. The distinct diurnal variations of COS uptake for the investigated trees indicated that COS uptake strongly depended on photosynthetically active radiation (PAR). The average COS uptake rates for most species were much higher in summer than in autumn, indicating leaf age and temperature also might be the important influencing factors for COS uptake. Platanus orientalis L., Sophara japonica var. P. loud., Magnolia denudata Desr. and Sophora japonica L. were capable of continuously absorbing COS in daytime as well as in nighttime. For Platanus orientalis L., the maximal COS uptake rate and DMS emission rate on a single leaf area basis were -15.29 and $0.42 \mathrm{pmol} \mathrm{m}^{-2} \mathrm{~s}^{-1}$, respectively. The COS exchange fluxes for the investigated tree species depended strongly on the ambient COS mixing ratios. Significant correlation between DMS emissions and temperature was observed in summer.
\end{abstract}

(C) 2005 Elsevier Ltd. All rights reserved.

Keywords: Carbonyl sulfide; Dimethyl sulfide; Exchange rate; Trees

\section{Introduction}

Atmospheric sulfur (S) cycling is largely linked to the activities of various biological processes occurring on the Earth's surface. Carbonyl sulfide (COS) and Dimethyl sulfide (DMS) are the most relevant reduced volatile $\mathrm{S}$ compounds involved in these interactive processes (de Mello and Hines, 1994). $\mathrm{COS}$ is the most abundant volatile-reduced sulfur compound and nearly inert to photochemical decomposition in the troposphere, thus a significant

\footnotetext{
*Corresponding author.

E-mail address: yjmu@mail.rcees.ac.cn (Y. Mu).
}

amount of COS can diffuse into the stratosphere, where it is converted to sulfate aerosols. This has been proposed as the primary mechanism by which the stratospheric sulfate aerosol layer is sustained during non-volcanic periods (Crutzen, 1976; Servant, 1986). More recent investigations have shown that shorter-lived sulfur species can be transported from near the Earth's surface into the stratosphere through convective activity (Rodhe, 1999). However, in the lower stratosphere, where the fluxes of the shorter-lived compounds are smaller, COS could be important also in context of fluxes and budget of sulfur (Kjellström, 1998). DMS has been hypothesized to be the principle 
precursor of cloud condensation nuclei $(\mathrm{CCN})$ in the marine troposphere, which are potentially important in regulating cloud optical properties and climate (Chalson et al., 1987). As a consequence of these environmental effects, considerable research has been devoted to assessing the global budget of these gases (Bartell et al., 1993; Berresheim and Vulcan, 1992; Brown and Bell, 1986; Chin and Davis, 1993; de Mello and Hines, 1994; Kuhn et al., 1999, 2000; Logan et al., 1979; Toon et al., 1987).

For COS, total global sources and sinks are estimated as $1.31 \pm 0.25$ and $1.66 \pm 0.79 \mathrm{Tg} \mathrm{a}^{-1}$ (Watts, 2000), respectively. For this gas, data on soil and vegetation fluxes are still sparse (Watts, 2000). The emissions of DMS from vegetation are also a little uncertain, as there seems an almost total dearth of data from temperate and boreal regions (Watts, 2000).

Deposition to vegetation has been thought of as the main sink for atmospheric COS (Brown and Bell, 1986; Chin and Davis, 1993; Logan et al., 1979; Toon et al., 1987) and until recently, a series of studies were conducted to better quantification of these processes (Bartell et al., 1993; Gries et al., 1994; Kesselmeier et al., 1993; Kesselmeier and Merk, 1993; Kuhn et al., 1999, 2000; Xu et al., 2002). However, there are only a few field measurements of the fluxes of the reduced sulfur gases by higher plant (Kesselmeier et al., 1993; Kesselmeier and Merk, 1993; Kuhn et al., 1999; Xu et al., 2002). Considering the importance of higher plant in estimating the global sources and sinks of the reduce sulfur gases, a better understanding of the role of higher plant is required.

Dynamic enclosure and micrometeorological method are commonly used for measuring reduced volatile sulfur gases by plants and soils. In the former, the enclosure may disturb the natural microclimate. The latter method needs large flat ground, sampling tower and complex meteorological instrumentations, which are not available at many sites. Static enclosure, a method used to estimate emission and consumption of carbon dioxide, nitrous oxide and methane in wide variety of continental environments (Bartlett et al., 1985; Crill et al., 1988; Khalil et al., 1991), has also been used to study the $\mathrm{S}$ fluxes in natural environments (Hines and Mrrison, 1992; De Mello and Hines, 1994; Geng and $\mathrm{Mu}, 2004)$. There are significant advantages of using the static enclosure system. The static enclosure system could mimic natural condi- tions at the time of initial sampling and the problem due to the change in the head gas composition could partly eliminate by extrapolating to $t=0$ (De Mello and Hines, 1994). Additionally, static enclosures simplify field equipment and samples acquisition. So a static enclosure was adopted in this study.

The objective of this study was to investigate COS and DMS exchange rates between trees and the atmosphere as well as the influencing factors (i.e., $\mathrm{CO}_{2}$ exchange, sunlight, temperature and leaf age etc.) in a typical temperate region of Beijing city. It was hoped that such a systematic investigation would extend the database for estimating the contribution of tree species in temperate region to the budget of COS on global scale.

\section{Experiment}

\subsection{Site description}

This study was preformed in Beijing Forestry University, Beijing (116E, 40N). Many trees growing at the site are representative for northern China. All the tree species at the site are deciduous and inactive in winter, except Cedrus deodara (Roxb.) loud. and Pinus tabulaeformis Carr., which are indeciduous.

\subsection{Enclosure system}

A static enclosure was used to measure the emission or consumption of COS and DMS between trees and the atmosphere. The enclosure $(0.35 \mathrm{~m} \times 0.35 \mathrm{~m} \times 0.30 \mathrm{~m})$ was constructed of Teflon film with aluminum bracket, which was also wrapped by Teflon film to insure the air in the enclosure only contact with Teflon film and leaves. The enclosure walls were not rigid and thus wall flexing, both manually and by the wind, were sufficient to effect uniform mixing. Fried et al. (1993) had confirmed that in all cases mixing occurred rapidly without the need for additional mechanical stirring for this kind of enclosure. A hole of the enclosure is allowed for insertion of a small branch that remained connected to the tree, and the hole was sealed by cotton as experiments being deployed.

Using a metal bellows pump (MP-30, SIBATA Scientific Technology Limited), four samples $(\sim 900 \mathrm{~mL})$ were drawn at $1 \mathrm{Lmin}^{-1}$ from the enclosure headspace at approximately $0.5,3,6$ and $9 \mathrm{~min}$ after the enclosure being deployed. All 
samples were collected into Teflon bags (the volume of the bag is $1 \mathrm{~L}$ ). Because the enclosure was made of Teflon film, which has good flexibility, the pressure change (4 samples account for only $10 \%$ of the total volume) caused by sampling may be negligible. These samples were analyzed within $2 \mathrm{~h}$ in our laboratory. The pump and the bag were tested for COS and DMS production or destruction, and no interference were found for COS and DMS during a short time contact ( $1 \mathrm{~min}$ for the pump and $2 \mathrm{~h}$ for the bag). Air temperature within the enclosure was recorded with a thermocouple. Photosynthetically active radiation (PAR) was measured with a LI-COR quantum sensor (LICOR, Lincoln, NE, USA) outside the enclosure.

\subsection{Analysis of trace gases}

COS and DMS in the air sample were preconcentrated onto a Teflon tube filled with TenaxGC, which was immersed in liquid nitrogen and analyzed on a gas chromatograph equipped with a flame photometric detector (GC-FPD). Detailed description of the method may be found in our previous studies (Geng and $\mathrm{Mu}, 2004$; $\mathrm{Mu}$ et al., 2002, 2004).

Control measurements of the empty enclosure were conducted regularly in order to evaluate possible loss or contamination problem of COS and DMS inside the enclosure. No effect of the enclosure could be detected within the precision of our system. The GC-FPD was calibrated with standard samples. DMS was from Germany (Chevron Phillips Chemicals Deutschland $\mathrm{GmbH}$ ) with a purity of greater than $99 \%$, and further purified by repeated freeze-pump-thaw cycles and fractional distillation before use. The standard gas of DMS was prepared as a static mixture of DMS vapor (the vapor pressure was measured by a capacitance manometer, 0-10 Torr, MKS, in a vacuum system) and nitrogen diluent in a $10 \mathrm{~L}$ glass-bulb. The standard material of COS $(2 \%$, $\operatorname{COS} / \mathrm{N}_{2}$ ), from Scott Specialty Gases Inc., had a certified accuracy of less than $\pm 5 \%$. The accuracy of our flow dilution is less than $\pm 5 \%$. Comparing the respond values between direct injection $(1 \mathrm{~mL})$ and the injection of the same amounts performed via concentration onto Tenax-GC, the recovery efficiencies for COS and DMS were about $94 \%$ and $100 \%$, respectively. The detection limits of COS and DMS for $800 \mathrm{~mL}$ air sample were approximate $0.88 \mathrm{pmol} \mathrm{L}^{-1}(20 \mathrm{ppt})$ and $0.49 \mathrm{pmol} \mathrm{L}^{-1}(11 \mathrm{ppt})$, respectively. The relative precisions of the method for COS and DMS were less than 6\% (the relative precision for COS based on reproducibility of consecutive samples over a 30-day period with compressed air sample of $40.49 \mathrm{pmol} \mathrm{L}^{-1}$ (907 pptv) (number of replicates $n=30$ ); for DMS based on reproducibility of a sample with $6.70 \mathrm{pmol} \mathrm{L}^{-1}$ $(150 \mathrm{pptv})(n=6))$.

$\mathrm{CO}_{2}$ was measured by using a GC-Ni catalyst converter-FID (GC 112A, Shanghai Precision \& Scientific Instrument CO., LTD) with $1 \mathrm{~mL}$ direct injection. Typical gas flow rates were: nitrogen (carrier gas, 99.999\%), $52 \mathrm{~mL} \mathrm{~min}^{-1}$; hydrogen, $17 \mathrm{~mL} \mathrm{~min}^{-1}$; compressed air, $252 \mathrm{~mL} \mathrm{~min}^{-1}$.

\subsection{Flux calculation}

The gas exchange rate $F$ based on single surface area and dry weight of leaves covered in the enclosure was calculated using the following equations:

$F=V[\mathrm{~d} C / \mathrm{d} t] / S$ or $F=V[\mathrm{~d} C / \mathrm{d} t] / W$,

where $V$ is the enclosure volume; $S$ is the single leaf area covered in the enclosure; $\mathrm{d} C / \mathrm{d} t$ is the slope of the curve of the gas concentration change with time ( $t$ ) in the enclosure headspace; $W$ is the dry weight of leaves covered in the enclosure. Dry weight was obtained by weighing the investigated leaves after drying at $90{ }^{\circ} \mathrm{C}$ for $24 \mathrm{~h}$ in an oven. The leaf area covered in the enclosure was measured by using a piece of paper. The leaf area was calculated using the following equation:

$S=S_{\text {total }} \times\left(W_{\text {total }}-W_{\text {remain }}\right) / W_{\text {total }}$,

where $S$ is the leaf area; $S_{\text {total }}$ is the total area of the paper; $W_{\text {total }}$ is the total weight of the paper; $W_{\text {remain }}$ is the weight of the paper after removing the shape of the leaf.

Because of the great variation of COS mixing ratios in the atmosphere in Beijing, deposition velocity was also used to illustrate the exchange between trees and the atmosphere. Deposition velocity $\left(v_{\mathrm{d}}\right)$ was derived from the measured flux $(F)$ and the COS ambient concentration $(C)$ :

$v_{\mathrm{d}}=-\frac{F}{C}$.

The following assumptions were made to calculate the errors of the exchange rates: $6 \%$ error for the gas measurements $\left(\sigma_{\mathrm{b}}\right), 5 \%$ error in volume of enrichment $\left(\sigma_{\mathrm{Q}}\right)$, and $1 \%$ in the surface area 
determination $\left(\sigma_{\mathrm{a}}\right)$ or in the dry weight determination $\left(\sigma_{\mathrm{w}}\right)$. The total flux error $\left(\sigma_{F}\right)$ can be obtained by using the error propagation method according to Doerffel (1984):

$\sigma_{F}=\sqrt{\sigma_{\mathrm{b}}^{2}+\sigma_{\mathrm{Q}}^{2}+\sigma_{\mathrm{a}}^{2}}, \sigma_{F}=\sqrt{\sigma_{\mathrm{b}}^{2}+\sigma_{\mathrm{Q}}^{2}+\sigma_{\mathrm{w}}^{2}}$.

\section{Results and discussions}

We investigated COS and DMS exchange rates between the trees and the atmosphere in Northern China from the autumn of 2002 to the autumn of 2003. The majority of the COS and DMS fluxes were calculated based on four or three headspace air samples (i.e., $n=4$ or 3 ). Because the variations of temperature and COS concentration in the chamber could affect $\mathrm{S}$ gas fluxes (Goldan et al., 1987; Kesselmeier et al., 1999), short deployment time was conducted to reduce the feedback mechanism. The deployment time for most flux measurements was 9 min in this study. In most cases, the change of COS concentration versus time was nonlinear, and only in early morning or at night, linear slope was observed. For DMS, only linear relationship was observed during the investigated period. For $\mathrm{CO}_{2}$, linear correlation was observed in most cases while nonlinear correlation was occasionally observed at midday.

For the nonlinear, to calculate $[\mathrm{d} C / \mathrm{d} t]_{t}=0$, the concentration versus time data were fitted to an exponential equation (de Mello and Hines, 1994). The correlation coefficients $\left(R^{2}\right)$ ranged between 0.95 and 1 , but usually exceeded 0.99 . Typical COS, DMS and $\mathrm{CO}_{2}$ time course plots are displayed in Fig. 1.

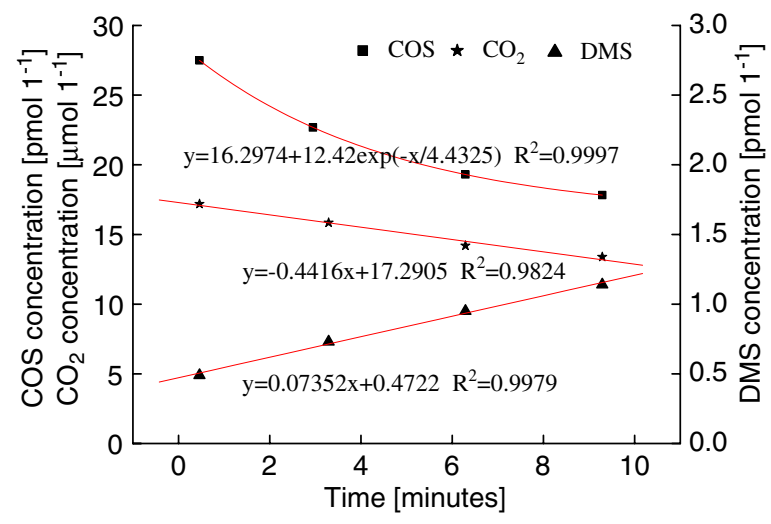

Fig. 1. Typical time courses for COS, DMS and $\mathrm{CO}_{2}$ concentrations within static enclosure on July 10th, 2003 (Platanus orientalis $L$., leaf area: $0.116 \mathrm{~m}^{2}$, dry weight: $6.423 \mathrm{~g}$ ).
DMS concentration for the first sample was sometimes too low (less than $0.49 \mathrm{pmol} \mathrm{L}^{-1}$ (11 ppt)) to be detected within $800 \mathrm{~mL}$ of collected air. However, some trees strongly emitted DMS that then could be detected after $30 \mathrm{~s}$ of accumulation.

Table 1 gives an overview of the exchange rates observed in autumn and summer. Only periods with continuous data under stable conditions are listed. For a specific tree, the COS exchange rates were at same level when the tree was under similar ambient conditions (PAR, temperature and COS concentration) and in same season, whereas there was large difference among COS exchange rates when the tree was exposed to different conditions, reflected by the large range of the fluxes. For different species, the COS exchange rates varied a lot. Among the six species investigated in the autumn of 2002, the uptake rates of COS by Platanus orientalis $L$. Sophora japonica $L$. and Salix babylonica $L$. were obvious, by Sophora japonica var. P. Loud. and Magnolia denudata Desr. were weak, whereas by Pinus tabulacformis Carr. was not found. Among the 18 tree species investigated in the summer of 2003, most of the trees acted as net sinks for COS. However, we also found a few trees emitting COS, such as Sophora japonica L., Salix matsudana Koidz. and Ulmus pumila L. Emission of COS by specific tree (loblolly pine) was also observed by Berresheim and Vulcan (1992), and they pointed out that the net exchange of COS between plants and the atmosphere may be plant-specific, i.e. certain plants may be net sources while others are net sinks for atmospheric COS. Our study provided further evidence for this conclusion.

For Platanus orientalis L., the uptake rates for $\mathrm{COS}$ in daytime and in the evening (PAR = $0 \mu \mathrm{mol} \mathrm{m}^{-2} \mathrm{~s}^{-1}$ ) were found to be in the range of -1.51 to -15.29 and $-1.45-0$ pmol $\mathrm{m}^{-2} \mathrm{~s}^{-1}$, respectively. The maximal DMS emission rate was $0.42 \mathrm{pmol} \mathrm{m}^{-2} \mathrm{~s}^{-1}$. The deposition velocities of COS were in the range from 0.049 to $0.29 \mathrm{~mm} \mathrm{~s}^{-1}$ in daytime and from 0 to $0.053 \mathrm{~mm} \mathrm{~s}^{-1}$ in the evening, respectively. The deposition velocities of COS obtained by this study were at the lower limit of reported values for various plants (see Table 2).

\subsection{Diurnal variations}

Three diurnal courses are selected to represent different variations of COS flux and the corresponding environmental parameters in further detail. (Figs. 2-4). 


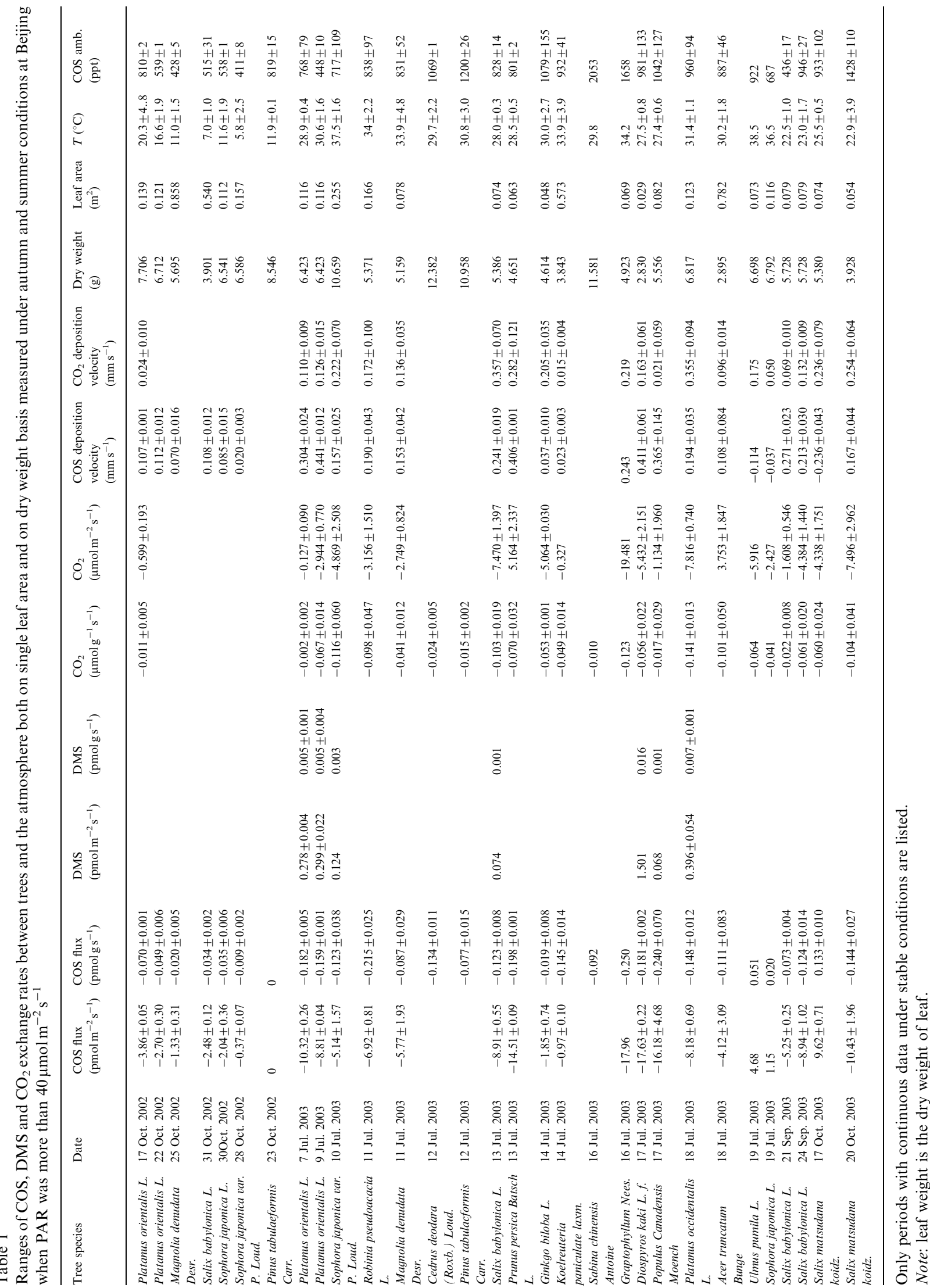


Table 2

COS uptake of Platanus orientalis L. in comparison with other plant species (cuvette studies under laboratory and field conditions)

\begin{tabular}{|c|c|c|c|c|}
\hline Species & $\begin{array}{l}\mathrm{COS} / \mathrm{CO}_{2}(\mathrm{pmol} \\
\left.\mu \mathrm{mol}^{-1}\right)\end{array}$ & $\begin{array}{l}\text { Deposition velocity } \\
\left(\mathrm{mm} \mathrm{s}^{-1}\right)\end{array}$ & $\begin{array}{l}\text { Light intensity } \\
\left(\mu \mathrm{E} \mathrm{m}^{-2} \mathrm{~s}^{-1}\right)\end{array}$ & $\begin{array}{l}\text { Reference (and cuvette } \\
\text { conditions) }\end{array}$ \\
\hline Platanus orientalis $L$. & $0.63-5.99$ & $0.049-0.29$ & $40-560$ & This work (field conditions) \\
\hline Salix babylonica L. & $0.54-5.18$ & $0.077-0.388$ & $60-790$ & This work (field conditions) \\
\hline $\begin{array}{l}\text { Sophara japonica var. } P \text {. } \\
\text { loud. }\end{array}$ & $1.51-1.54$ & $0.06-0.15$ & $392-607$ & This work (field conditions) \\
\hline $\begin{array}{l}\text { Koelreuteria paniculate } \\
\text { laxm. }\end{array}$ & $2.10-4.51$ & 0.01 & $171-240$ & This work (field conditions) \\
\hline Prunus persica Batsch L. & $1.95-5.10$ & 0.20 & $165-278$ & This work (field conditions) \\
\hline Diospyros kaki L. $f$. & $2.35-5.31$ & $0.18-0.24$ & $33-53$ & This work (field conditions) \\
\hline Rapeseed & $0.9-1.4$ & $1.1-1.5$ & 600 & $\begin{array}{l}\text { Kesselmeier and Merk } \\
\text { (1993) (laboratory } \\
\text { conditions) }\end{array}$ \\
\hline Corn & $1.9-16.7$ & $0.3-0.9$ & $150-1200$ & \\
\hline Crops & & $1.3-3.3$ & 600 & $\begin{array}{l}\text { Goldan et al., (1988) } \\
\text { (laboratory conditions) }\end{array}$ \\
\hline $\begin{array}{l}\text { Vegetables (Spinacea } \\
\text { aleracea, Allium cepa, } \\
\text { Lacruca sativa, Rhaphanus } \\
\text { sativus, Brassica oleracea) }\end{array}$ & & $0.25-0.6$ & 350 & $\begin{array}{l}\text { Kluczewski et al. (1985) } \\
\text { (laboratory conditions) }\end{array}$ \\
\hline Tropical forest & & & & $\begin{array}{l}\text { Kesselmeier et al. (1993) } \\
\text { (field conditions) }\end{array}$ \\
\hline $\begin{array}{l}\text { Sacoglottis } \\
\text { gabonensis(canopy top) }\end{array}$ & $0.8-38.4$ & & & \\
\hline $\begin{array}{l}\text { Sacoglottis } \\
\text { gabonensis(ground level) }\end{array}$ & $0.3-23.4$ & & & \\
\hline $\begin{array}{l}\text { Porterandia cladatha } \\
\text { (ground level) }\end{array}$ & $0.1-6.0$ & & & \\
\hline Quercus petrea & 2.2 & & $0-520$ & $\begin{array}{l}\text { Velmeke, (1993) (laboratory } \\
\text { conditions) }\end{array}$ \\
\hline
\end{tabular}

Note: $\mathrm{COS} / \mathrm{CO}_{2}$ indicates the relation between $\mathrm{COS}$ uptake and $\mathrm{CO}_{2}$ assimilation; calculated deposition velocities relate to 'single sided' leaf surface area.

The diurnal variations of COS exchange rates and the environmental parameters for Platanus orientalis L. (July 15, 2003) and Salix babylonica L. (September 27, 2003) are shown in Figs. 2 and 3, respectively. The distinct diurnal variations of COS deposition velocities for the two trees had similar trend with $\mathrm{CO}_{2}$ deposition velocities, indicating that the investigated trees took up COS mainly via their stomata (Kesselmeier and Merk, 1993). It is interesting to be noted that the maximal COS deposition velocity for Platanus orientalis $L$. appeared (at LT 10:35) before the maximal values of PAR and temperature (at LT 14:00), whereas the maximal COS deposition velocity for Salix babylonica $L$. was in accordance with the maximal values of PAR and temperature. The temperature after LT 10:35 during investigation period for Platanus orientalis $L$. exceeded $30^{\circ} \mathrm{C}$, while for Salix babylonica L., all temperature were below $30^{\circ} \mathrm{C}$.
High temperature might restrain COS exchange and result in the slow COS deposition velocity for Platanus orientalis $L$. when temperature exceeded $30{ }^{\circ} \mathrm{C}$. The coincident maximal COS deposition velocities of the two trees appeared around $30^{\circ} \mathrm{C}$, indicating the temperature of $30^{\circ} \mathrm{C}$ might be the optimal temperature for COS uptake by plants if the influences of other factors were excluded.

To better understanding of the COS exchange behavior between willow and the atmosphere, we also investigated COS exchange between Salix matsudana koidz. and the atmosphere in October, 2003. During this investigated period, the temperature was relatively high and most of the temperature was above $15^{\circ} \mathrm{C}$. The leaves were still green. Though the $\mathrm{CO}_{2}$ deposition velocities were at the same level as Salix babylonica L. in September, both uptake and emission for COS were observed (Fig. 4). Salix matsudana koidz. acted as a COS 

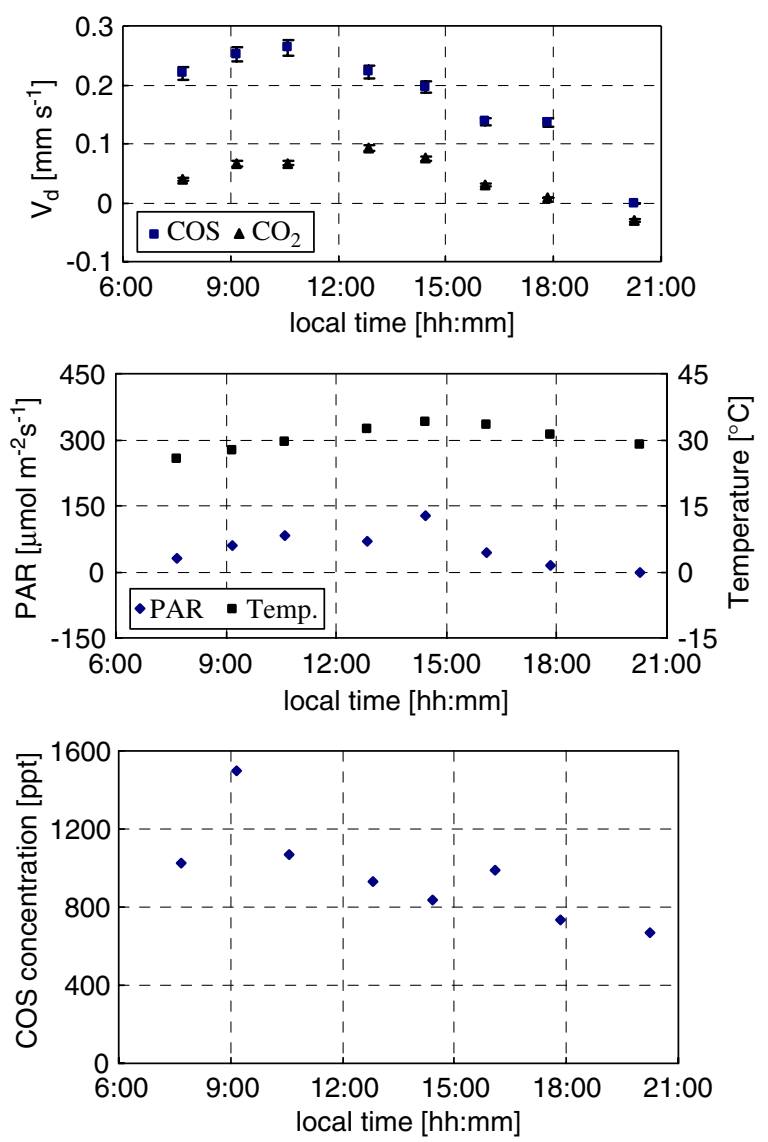

Fig. 2. Diurnal cycle of the COS uptakes by Platanus orientalis $L$. together with the eco-physiologically relevant parameters on July 15, 2003. Error bars of COS exchange indicate the total flux error according to Eq. (4) $(n=8)$.

source when the light and temperature were high, while COS uptake appeared at early morning. The ambient $\operatorname{COS}$ concentrations in this day were relatively stable $(500-800 \mathrm{ppt})$ except one high concentration appeared in the evening, the emission cannot be ascribed to COS ambient concentration. So, the leaves' senescence and other factors might be the reason for this emission.

We also found DMS emissions from some tree species in summer during our experiment (Table 1). Assuming the whole surface of temperate region was covered by vegetations with maximum of DMS emission rate $\left(1.50 \mathrm{pmol} \mathrm{m}^{-2} \mathrm{~s}^{-1}\right.$, Table 1$)$ as investigated in this study; we could obtain an annual DMS flux as about $2.90 \times 10^{-3} \mathrm{~g} \mathrm{~m}^{-2} \mathrm{a}^{-1}$. This value was one magnitude less than that from the tropical vegetations (the average annual flux from tropical forests of $72.5 \pm 21.8 \times 10^{-3} \mathrm{~g} \mathrm{~m}^{-2} \mathrm{a}^{-1}$ (Watts, 2000)). It should be mentioned that the
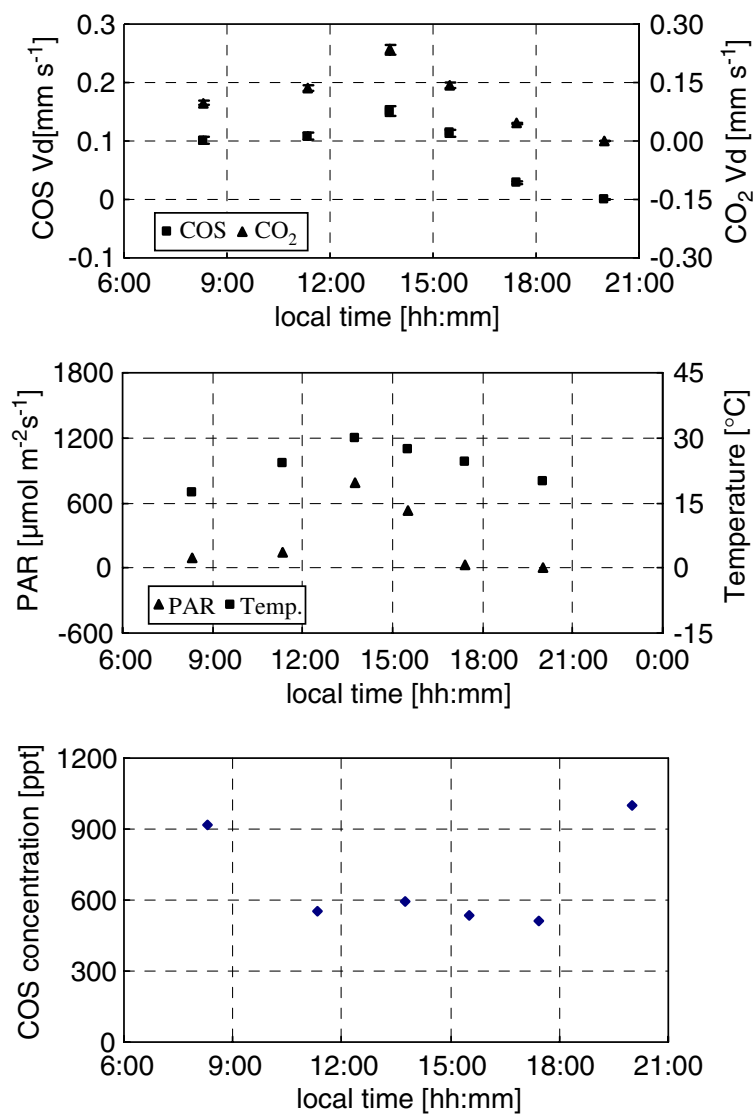

Fig. 3. Diurnal cycle of the COS uptakes by Salix babylonica $L$. together with the eco-physiologically relevant parameters on September 27, 2003. Error bars of COS exchange indicate the total flux error according to Eq. (1).

maximum of DMS emission flux was only obtained in summer for specific tree species and DMS emission rates for most investigated tree species were much lower than the maximum or without DMS emission. The annual DMS flux obtained above must be overestimated. Therefore, compared with the annual flux from tropical forests, the contribution of temperate tree species to the global atmospheric DMS could be negligible. However, DMS emissions from the tree species may have influence on regional environment because of its important environmental effect.

\subsection{Factors impacting on $S$ gases exchanging rates}

S gases exchanging rates between plants and the atmosphere are affected by many factors such as the ambient $\mathrm{S}$ concentration, PAR, temperature, relative humidity, species and leaf age etc. (Fall et al., 

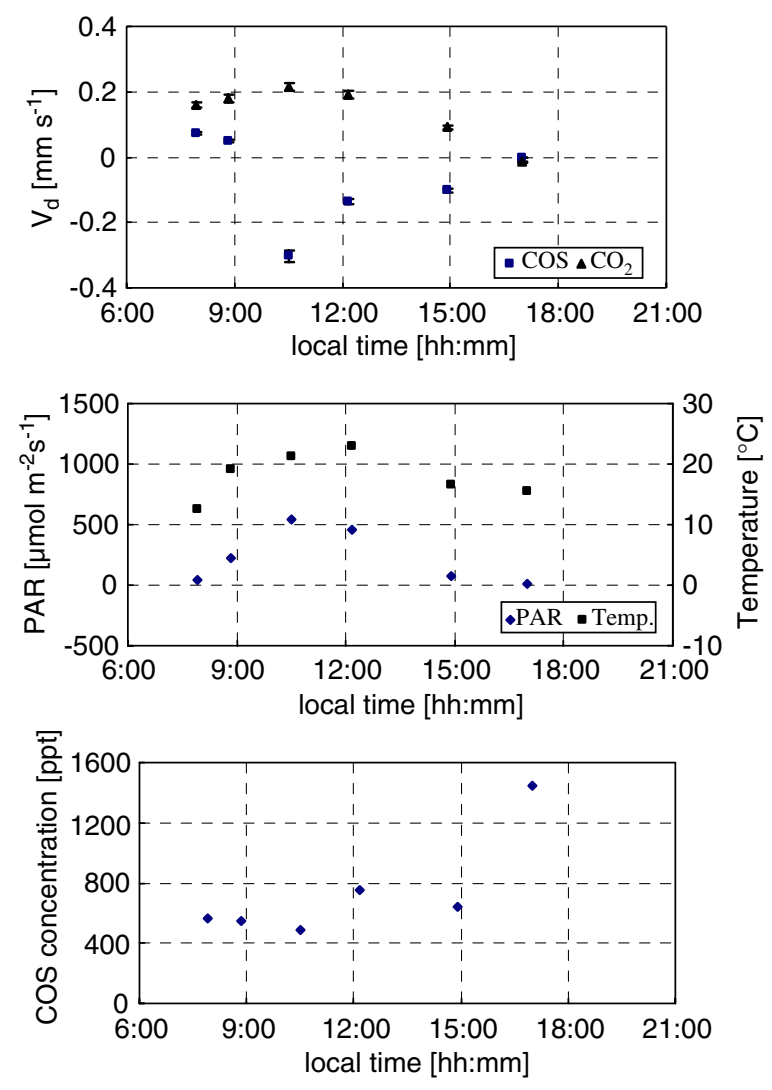

Fig. 4. Diurnal cycle of the COS uptakes by Salix matsudana koidz. together with the eco-physiologically relevant parameters on October 22, 2003. Error bars of COS exchange indicate the total flux error according to Eq. (1).

1988; Kuhn et al., 1999, 2000). Most of the impacting factors were implied by above results and will be further discussed one by one in the following sections.

\subsubsection{COS ambient concentration}

According to Remde et al. (1989) and Conrad (1994), the gas exchange can be discussed as a result of simultaneously operating production and consumption processes. The consumption rate is assumed to be a function of trace gas concentration, whereas the production rate is not. This implies the existence of a so-called compensation point (Kesselmeier et al., 1999), that is, the net flux is zero.

COS exchanging fluxes of Platanus orientalis $L$. versus COS concentration is shown in Fig. 5, which was measured in July 2003. It is evident that COS uptake rates increased with increasing COS ambient concentration. The good linear correlation $\left(R^{2}=0.91, n=18\right)$ indicated that ambient COS concentration was an important influencing factor

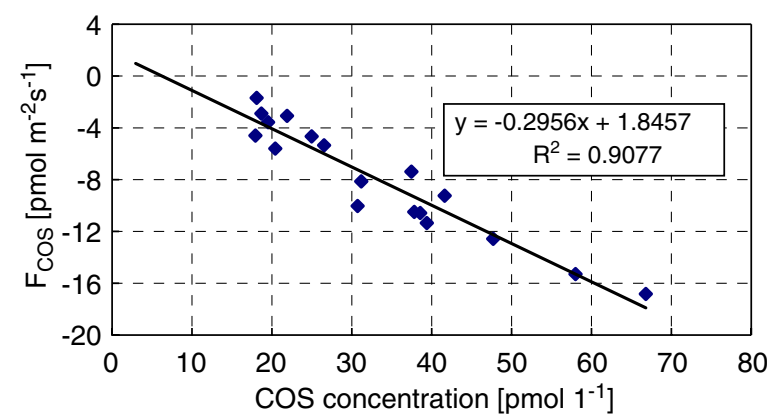

Fig. 5. COS fluxes of Platanus orientalis $L$. versus the ambient mixing ratio inside the enclosure in July $2003(n=18)$.

for COS exchange. The COS compensation point could be derived from Fig. 5 as about 6.24 pmoll $^{-1}$ (140 ppt), which was within the compensation point values of $4.02-6.70 \mathrm{pmol}^{-1}(90-150 \mathrm{ppt})$ for some plants reported by Kesselmeier and Merk (1993). Table 3 shows the compensation points and the linear coefficients for Platanus orientalis L., Salix matsudana koidz. and Salix babylonica L. Only data that were measured under PAR $>40 \mu \mathrm{mol} \mathrm{m}^{-2} \mathrm{~s}^{-1}$ conditions were included. It is interesting to note that the compensation point for a specific tree shift to higher value as leaves turning to older. Leaves senescence might partly be responsible for these high compensation points. High compensation points of Salix babylonica L. and Salix matsudana koidz. in October indicated that they should be considered as a source of COS under typical natural ambient COS concentration of $22.32 \pm 4.46 \mathrm{pmoll}^{-1}$ $(500 \pm 100 \mathrm{ppt})$.

\subsection{2. $P A R$}

The similar trends of the diurnal variations of COS uptake and PAR as shown in Figs. 2 and 3 indicated that PAR might be an important influencing factor for COS uptake. PAR is closely correlated with photosynthetic $\mathrm{CO}_{2}$ uptake, the importance of PAR on COS uptake can be explained by comparing COS uptake with the photosynthetic $\mathrm{CO}_{2}$ uptake.

Previous studies indicated that COS uptake was closely correlated with photosynthetic $\mathrm{CO}_{2}$ uptake (Kesselmeier and Merk, 1993; Kuhn et al., 1999). Good linear correlations between COS uptake rates and $\mathrm{CO}_{2}$ assimilation rates were also found for Platanus orientalis L. and Salix babylonica L. during the diurnal variation measurements (Figs. 2 and 3 ). The linear correlation coefficient $\left(R^{2}\right)$ for Platanus orientalis $L$. was $0.80(n=8, \alpha=0.01)$ and resulted 
Table 3

COS compensation points and correlation coefficients $\left(R^{2}\right)$ for Platanus orientalis L., Salix babylonica L. and Salix matsudana koidz.

\begin{tabular}{lll}
\hline Tree species & Period & Compensation point \\
\hline Platanus orientalis $L$. & July, 2003 & $6.25 \mathrm{pmoll}^{-1}(140 \mathrm{ppt})\left(n=18, R^{2}=0.91\right)$ \\
Platanus orientalis $L$. & October, 2002 & $15.36 \mathrm{pmoll}^{-1}(344 \mathrm{ppt})\left(n=12, R^{2}=0.72\right)$ \\
Salix babylonica $L$. & October, 2002 & $38.62 \mathrm{pmoll}^{-1}(865 \mathrm{ppt})\left(n=5, R^{2}=0.87\right)$ \\
Salix babylonica $L$. & September, 2003 & $17.54 \mathrm{pmoll}^{-1}(393 \mathrm{ppt})\left(n=18, R^{2}=0.76\right)$ \\
Salix matsudana koidz. & October, 2003 & $36.96 \mathrm{pmoll}^{-1}(828 \mathrm{ppt})\left(n=17, R^{2}=0.73\right)$ \\
\hline
\end{tabular}

in a ratio of $2.53 \mathrm{pmol} \operatorname{COS} \mu \mathrm{mol}^{-1} \mathrm{CO}_{2}$. For Salix babylonica L., the linear correlation between COS uptake rates and $\mathrm{CO}_{2}$ assimilation rates was also significant $\left(R^{2}=0.87, n=6, \alpha=0.01\right)$ and resulted in a ratio of $1.05 \mathrm{pmol}^{\mathrm{COS}} \mu \mathrm{mol}^{-1} \mathrm{CO}_{2}$. It should be mentioned that there was no linear correlation between $\mathrm{COS}$ uptake rates and $\mathrm{CO}_{2}$ assimilation rates for any tree by using all data investigated in this study, resulting in large variations of the ratios of $\mathrm{COS}$ uptake rates and $\mathrm{CO}_{2}$ assimilation rates for the investigated trees. This might be due to large variation of $\mathrm{COS}$ mixing ratio in Beijing city. The ratios of $\mathrm{COS}$ uptake rates and $\mathrm{CO}_{2}$ assimilation rates for the six investigated tree species are listed in Table 2. The ratios obtained by this study were in good agreement with the reported values for different vegetations investigated under laboratory and field conditions.

We also observed that Platanus orientalis L., Sophara japonica var. P. loud., Magnolia denudata Desr. and Sophora japonica L. were capable of continuously absorbing COS in nighttime, with maximal deposition velocities of $0.053,0.037,0.062$, $0.051 \mathrm{~mm} \mathrm{~s}^{-1}$, respectively. The only biological COS consumption process that has been elucidated so far is the hydrolysis of $\mathrm{COS}$ to $\mathrm{H}_{2} \mathrm{~S}$ and $\mathrm{CO}_{2}$, which is strongly enhanced by the enzyme carbonic anhydrase (Kesselmeier et al., 1999; Protoschill-Krebs and Kesselmeier, 1992; Protoschill-Krebs et al., 1995, 1996), which is a light-independent enzyme (Protoschill-Krebs et al., 1996). So, COS could still be consumed by the enzyme carbonic anhydrase under dark condition as long as plant could take up COS via the leaf stomata or the leaf cuticle. For these tree species with COS uptake at night, COS uptake resistances might be low enough for COS uptake under dark condition.

\subsubsection{Temperature}

The enzyme carbonic anhydrase is considered to be responsible for the consumption of COS by higher plant (Kesselmeier et al., 1999; ProtoschillKrebs and Kesselmeier, 1992; Protoschill-Krebs et al., 1995, 1996). Temperature is vital to the enzyme activity. The activity of the enzyme will decrease when the temperature range exceeds a certain value owing to reorganization and/or denaturation of the enzyme structures (Kesselmeier et al., 1999). Temperature also plays an important role on regulating leaf stomata, via which plants take up COS. Under conditions of severe heat stress, most plants have mechanisms for reducing water transpiration by closing leaf stomata (Goldan et al., 1988). Such a response would, of course, significantly affect the uptake of gas phase compounds by the leaves. During our experiment in autumn, 2002, the highest temperature was $25.8^{\circ} \mathrm{C}$ and the lowest temperature was $0.8^{\circ} \mathrm{C}$. After October 21, the highest temperature was only $14.5^{\circ} \mathrm{C}$ and the temperature was near zero at night. The cold condition as well as senescence of leaves might result in the relatively low COS uptakes in autumn (Table 1). As for Sophora japonica L. and Magnolia denudata Desr., the average temperature in the chamber were $34.0^{\circ} \mathrm{C}$ when our experiments were deployed in summer. Too high temperature might have an influence on chemical as well as biological reactions and increase water loss, and resulted in low COS exchange rates for the two trees.

During summer, DMS production rate of Platanus orientalis $L$. increased with increasing ambient temperature and the correlation coefficient $\left(R^{2}\right)$ was $0.62(\alpha=0.01, n=13)$, which further confirmed the temperature dependence of DMS emissions from plants (Fall et al., 1988). In autumn, DMS emission could only be observed occasionally due to the low temperature. It should be noted that no DMS exchange at night was found in summer and autumn. The mechanism of DMS emission needs to be further studied. 
Table 4

Average of COS deposition velocity $\left(\mathrm{mm} \mathrm{s}^{-1}\right)$ between trees and the atmosphere in daytime on a single leaf area basis measured under autumn and summer conditions at Beijing

\begin{tabular}{lll}
\hline Species & Deposition velocity (autumn) & Deposition velocity (summer) \\
\hline Platanus orientalis L. & $0.095(n=9)$ & $0.22(n=19)$ \\
Magnolia denudata Desr. & $0.073(n=4)$ & $0.076(n=2)$ \\
Salix babylonica L. & $0.082(n=4)$ & $0.12(n=2)$ \\
Sophora japonica L. & $0.13(n=4)$ & $0.065(n=1)$ \\
Sophora japonica var. P. Loud. & $0.032(n=3)$ & $0.11(n=2)$ \\
Pinus tabulacformis Carr. & $0^{*}(n=6)$ & $16.56^{*}(n=2)$ \\
\hline
\end{tabular}

" $n$ " is the number of exchange rate measurements by this study. Note: *represents the COS flux $\left(\mathrm{ng} \mathrm{g}^{-1} \mathrm{~s}^{-1}\right)$.

\subsubsection{Leaf age}

The average values of COS deposition velocities for the six tree species investigated both in autumn and in summer are listed in Table 4. Goldan et al. (1988) pointed out that a light intensity as low as $40 \mu \mathrm{mol} \mathrm{m}{ }^{-2} \mathrm{~s}^{-1}$ resulted in apparently full saturation of COS uptake for soybeans, corn and wheat. To differentiate between PAR and leaf age regulated COS uptake by the trees, only the data when the light intensity was over $40 \mu \mathrm{mol} \mathrm{m}{ }^{-2} \mathrm{~s}^{-1}$ were presented in Table 4 . It could be seen that the average COS deposition velocities of Platanus orientalis L., Salix babylonica L., Sophora japonica var. P. Loud. and Pinus tabulacformis Carr. were 1.4 times higher in summer than in autumn. And the leaf age was about 90 days younger in summer than in autumn. Therefore, in addition to temperature (as discussed in Section 3.2.3), leaf age might be an important factor influencing COS uptake by these trees. The larger average COS uptake rate might partly be ascribed to the younger leaf age in summer.

\section{Conclusion}

The present work further confirmed that most of tree species acted as sinks for atmospheric COS. The results of this study will extend the database for accurately assessing the budget of atmospheric COS.

The contribution of the emissions of DMS for some tree species in temperate regions to the global DMS budget should be negligible. The emission of DMS from temperate tree species may have impact on regional environment.

A few of the tree species investigated in this study have high COS compensation points (greater than
500 pptv), these trees should be considered as a source of COS under typical natural ambient COS concentration $(500 \pm 100 \mathrm{ppt})$. Our results provide further evidence that the net exchange of COS between plants and the atmosphere may be plantspecific (Berresheim and Vulcan, 1992). Some tree species investigated in this study could consume COS during nighttime. Although the uptake rates were smaller in nighttime than in daytime, the contribution of COS consumption in nighttime could not be negligible. Therefore, to better assess global COS budget, more extensive field works are needed to re-assess the role of various vegetations to global atmospheric COS.

\section{Acknowledgments}

This work was supported by grants from $\mathrm{Na}$ tional Basic Research Program of China (2005CB422206) and NSF (China) (20277044).

\section{References}

Bartlett, K.B., Harriss, R.C., Sebacher, D.I., 1985. Methane flux from coastal salt marshes. Journal of Geophysical Research 90, 5710-5720.

Bartell, U., Hofmann, U., Hofmann, R., Kreuzburg, B., Andreae, M.O., Kesselmeier, J., 1993. COS and $\mathrm{H}_{2} \mathrm{~S}$ fluxes over a wet meadow in relation to photosynthetic activity: an analysis of measurements made on 6 September 1990 Atmospheric Environment 27A, 1851-1864.

Berresheim, H., Vulcan, V.D., 1992. Vertical distributions of $\mathrm{COS}, \mathrm{CS}_{2}$, DMS and other sulfur compounds in a loblolly pine forest. Atmospheric Environment 26A (11), 2,031-2,036.

Brown, K.A., Bell, J.N.B., 1986. Vegetation: the missing sink in the global cycle of OCS. Atmospheric Environment 20, 537-540. 
Chalson, R.J., Lovelock, J.E., Andreae, M.O., Warren, SG., 1987. Oceanic phytoplankton, atmospheric sulphur, cloud albedo and climate. Nature 326, 655-661.

Chin, M., Davis, D.D., 1993. Global sources and sinks of OCS and $\mathrm{CS}_{2}$ and their distribution. Global Biogeochemical Cycles 7, 321-337.

Conrad, R., 1994. Compensation concentration as a critical variable for regulating the flux of trace gases between soil and atmosphere. Biogeochemistry 27, 155-170.

Crill, P.M., Bartlett, K.B., Harriss, R.C., Gorham, E., Verry, E.S., Sebacher, D.I., Madzar, L., Sanner, W., 1988. Methane flux from Minnesota peatlands. Global Biogeochemical Cycles 2, 371-384.

Crutzen, P.J., 1976. The possible importance of OCS for the sulfate layer of the stratosphere. Geophysical Research Letter 3, 73-76.

De Mello, W.Z., Hines, M.E., 1994. Application of static and dynamic enclosures for determining dimethyl sulfide and carbonyl sulfide exchange in Sphagnum peatlands: implications for the magnitude and direction of flux. Journal of Geophysical Research 99, 14604-14607.

Doerffel, K., 1984. Statistik in der analytischen Chemie, third ed. Verlag Chemie, Weinheim, Germany.

Fall, R., Albitton, D.L., Fehsenfeld, R.C., Kuster, W.C., Goldan, P.D., 1988. Laboratory studies of some environmental variables controlling sulfur emissions from plants. Journal of Atmospheric Chemistry 6, 341-362.

Fried, A., Klinger, L.F., Erisckson III., D.J., 1993. Atmospheric carbonyl sulfide exchange in bog microcosm. Geophysical Research Letter 20, 129-132.

Geng, C., Mu, Y., 2004. Carbonyl sulfide and dimethyl sulfide exchange between lawn and the atmosphere. Journal of Geophysical Research 109 (D12302).

Goldan, P.D., Kuster, W.C., Albritton, D.L., Fehsenfeld, F.C., 1987. The measurement of natural sulfur emissions from soil and vegetation: three sites in the eastern United States revisited. Journal of Atmospheric Chemistry, 5439-5467.

Goldan, P.D., Fall, R., Kuster, W.C., Fehsenfeld, F.C., 1988. Uptake of COS by growing vegetation: A major tropospheric sink. Journal of Geophysical Research 93, 14,186-14,192.

Gries, C., Nash III., T.H., Kesselmeier, J., 1994. Exchange of reduced sulfur gases between lichens and the atmosphere. Biogeochemistry 26, 25-39.

Hines, M.E., Mrrison, M.C., 1992. Emissions of biogenic sulfur gases from Alaskan tundra. Journal of geophysical research 97, 16,703-16,707.

Kesselmeier, J., Merk, L., 1993. Exchange of COS between agriculture plants and the atmosphere: studies on the deposition of COS to peas, corn and rapeseed. Biogeochemistry $23,47-59$.

Kesselmeier, J., Meixner, F.X., Hofmann, U., Ajavon, A.L., Leimbach, S., Andreae, M.O., 1993. Reduced sulfur compound exchange between the atmosphere and tropical tree species in southern Cameroon. Biogeochemistry 23, 23-45.

Kesselmeier, J., Teusch, N., Kuhn, U., 1999. Controlling variables for the uptake of atmospheric carbonyl sulfide by soil. Journal of Geophysical Research 104 (D9), 11577-11584.
Khalil, M.A., Rasmussen, R.A., Wang, M.X., Ren, L., 1991. Methane emissions from rice fields in China. Environmental Science and Technology 25, 979-981.

Kjellström, E., 1998. A three-dimensional global model study of carbonyl sulfide in the troposphere and the lower stratosphere. Journal of Atmospheric Chemistry 29, 151-177.

Kluczewski, S.M., Brown, K.A., Bell, J.N., 1985. Deposition of $\left({ }^{35} \mathrm{~S}\right)$-carbonyl sulfide to vegetable crops. Radiation Protection Dosimetry 11, 173-177.

Kuhn, U., Ammann, C., Wolf, A., Meixner, F.X., Andreae, M.O., Kesselmeir, J., 1999. Carbonyl sulfide exchange on an ecosystem scale: soil represents a dominant sink for atmospheric OCS. Atmospheric Environment 33, 995-1008.

Kuhn, U., Wolf, A., Gries, C., Nash III., T.H., Kesselmeir, J., 2000. Field measurements on the exchange of carbonyl sulfide between lichens and the atmosphere. Atmospheric Environment 34, 4867-4878.

Logan, J.A., McElroy, M.B., Prather, M.J., 1979. Oxidation of $\mathrm{CS}_{2}$ and OCS: SO sources for atmospheric $\mathrm{SO}_{2}$. Nature 281, 185-188.

Mu, Y., Wu, H., Zhang, X., Jiang, G., 2002. The impact of anthropogenic sources on carbonyl sulfide in Beijing city. Journal of Geophysical Research 107 (D24).

Mu, Y., Geng, C., Wang, M., Wu, H., Zhang, X., Jiang, G., 2004. Photochemical production of carbonyl sulfide in precipitation. Journal of Geophysical Research 109 (D13301).

Protoschill-Krebs, G., Kesselmeier, J., 1992. Enzymatic pathways for the consumption of carbonyl sulfide (COS) by higher plants. Botanica Acta 105, 206-212.

Protoschill-Krebs, G., Wilhelm, C., Kesselmeier, J., 1995. Consumption of COS by Chlamydomonas reinhardtii with different activities of carbonic anhydrase (CA) induced by different $\mathrm{CO}_{2}$ growing rates. Botanica Acta 108, 445-448.

Protoschill-Krebs, G., Wilhelm, C., Kesselmeier, J., 1996. Consumption of COS by higher plant carbonic anyhydrase (CA). Atmospheric Environment 30 (N18), 3151-3156.

Remde, A., Slemr, F., Conrad, R., 1989. Microbial production and uptake of nitric oxide in soil. FEMS Microbiological Ecology 62, 221-230.

Rodhe, H., 1999. Human impact on the atmospheric sulfur balance. Tellus A-B, 110-122.

Servant, J., 1986. The burden of the sulphate layer of the stratosphere during volcanic "quiescent" periods. Tellus 38 (B), 74-79.

Toon, O.B., Kasting, J.B., Turco, R.P., Liu, M.S., 1987. The sulfur cycle in the marine atmosphere. Journal of Geophysical Research 92, 943-963.

Velmeke, 1993. Versuche zur Korrelation von Photosynthese mit dem Austausch flüchtiger Schwefelverbindungen zwischen Bäumen und der Atmosphäre. Diploma Thesis, Johannes Gutenberg University, Mainz.

Watts, S.F., 2000. The mass budgets of carbonyl sulfide, dimethyl sulfide, carbon disulfide and hydrogen sulfide. Atmospheric Environment 34, 761-779.

Xu, X., Bingemer, H.G., Schmidt, U., 2002. The flux of carbonyl sulfide and carbon disulfide between the atmosphere and a spruce forest. Atmospheric Chemistry Physics 2, 171-181. 